\title{
Institutionalised corruption in Indonesian irrigation: An analysis of the upeti system
}

\author{
Diana Suhardiman and Peter P. Mollinga \\ Accepted for publication in Development Policy Review
}

March 2016

\begin{abstract}
Institutionalised corruption is an enduring feature of state governance in Indonesia. This article analyses the internal logic of the upeti system, how it was established during the New Order government and its continuation in the post-Soeharto era. It brings to light how corruption rules are shaped through complex socio political relationships reflected in the organisational culture of the irrigation agency. Using an anthropological approach to corruption, the article brings to light: 1) the importance of social relations in shaping institutionalised corruption; 2) how the upeti system justifies corruption practices as the prevailing social norm; and 3) the need for structural change within the existing political and bureaucratic systems to eradicate corruption. Illustrating how corruption rules are embedded in project management procedures, with projects highly dependent on donor funding, it highlights the issue's importance for international agencies and development programmes and the need to be more self-consciously and politically aware in promoting their development agenda.
\end{abstract}

Keywords: corruption, government bureaucracy, irrigation sector, Indonesia; Asia

\section{Introduction}

Institutionalised corruption is an enduring feature of state governance in Indonesia (Hellman and Kaufman, 2001). Created and established during Soeharto's thirty two years reign, bureaucratic rent seeking has become part of government bureaucratic mechanisms and is linked with systemic political corruption (Bull and Newell, 1997; Hopkin, 1997). The system has been 
described by McLeod (2008) as the 'Soeharto franchise', portraying a giant extraction machinery created to secure political survival of the regime and engender loyalty of bureaucrats to it. ${ }^{1}$ Blunt et al. (2012a) and Hadiz (2004) provide a comprehensive account of the continuation of patronage based governance in post-Soeharto Indonesia, while a growing number of sector wise case studies is becoming available on contemporary instances of corruption in Indonesia (see Blunt et al. (2012b) on education and health; Olken, 2006 on anti poverty programmes; Rosser and Wilson, 2012 on health care; Smith et al., 2003 on logging).

That international development assistance has enhanced and is supporting patronage politics is not a new insight. ${ }^{2}$ Our analysis shows that, indeed, the irrigation sector is one of the 'so-called 'wet' agencies (those with access to the development budget and to donor funds)' (Blunt et al., 2012a: 70). We will show that also for irrigation 'development assistance is a prime target for predation by patronage networks and (...) collusion between patronage networks and implementing agents in such predation is likely’ (Blunt et al., 2012a: 76).

\footnotetext{
${ }^{1}$ See Bardhan (1997); Kaufmann and Kraay (2002); Treisman (2007) on the link between corruption and development. See also Ngo (2008) on how institutionalised corruption could coexist with good development performance, under corrupt authoritarian rule in China.

${ }^{2}$ See McLeod (2008: 212): 'Within the bureaucracy, management would ordinarily devote part of the socalled 'development' budget, largely deriving from bilateral and multilateral aid agencies, to the payment of various allowances, for example, to people who served on project committees and, through them, to both their superiors and subordinates in the same area'.
} 
While there may be agreement on the existence of systemic corruption and the tenacity of patronage based governance in Indonesia in the post-Soeharto period ${ }^{3}$, there exists a diversity of approaches to and opinions on two questions: 1) how can institutionalised corruption be best analysed and interpreted? 2) how should corruption (therefore) be addressed in policy and practice? This article addresses both questions ${ }^{4}$, using the irrigation sector as its example, while critically engaging with the literature on corruption in Indonesia and the water sector generally.

The article's contribution to the analysis of corruption lies in enhancing what might be called a 'critical' approach to corruption. Critical in the sense of questioning the way corruption is treated within the mainstream (presently neoliberal) development orthodoxy. Dominated by neoinstitutional economics perspectives, this orthodoxy focuses on the management of 'incentives'. For instance, McLeod's analysis and approach to reduce corruption are basically a 'getting the prices right' perspective. He argues that 'corruption is only a symptom of a fundamental problem of inappropriate personnel management practices in the bureaucracy' (2008: 200). The prices that need to be set right are the salaries of civil servants managers, their present low level explaining the propensity to corrupt behaviour. This analysis is in line with the World Bank's favouring of "appropriate compensation packages" (World Bank, 2003: 107 cited in Blunt et

\footnotetext{
${ }^{3}$ We agree with Robbins (2000:439) when he states that 'corruption is an institution, not the absence of one'. For general debate on corruption and strong/weak state institutions, see Goudie and Stasavage (1998) and Darden (2008); on corruption as social relationship and its importance for neo-patrimonial states, see Evers (1985); Moe (1989); for definitions of corruption see Lu (2000: 275); Johnston (1986). ${ }^{4}$ In this article we focus mainly on the presentation of our key findings on the role of social relationships and organisational culture in shaping institutionalised corruption, and how this contributes to the overall discussions on how corruption should be addressed in policy and practice. While we also include how some mid career officials from the irrigation agency envisioned to address corruption, we present this merely as additional information in our analysis, and not as our main source of data to answer the second research question separately.
} 
al., 2012a: 70). Blunt et al. (2012a) label such approaches as 'technocratic reform', and they argue, in our view convincingly, that the optimism about the efficacy of such approaches is misplaced. Moreover, they argue that 'the strength and convenience of (mistaken) neoinstitutionalist convictions concerning the efficacy of technocratic reform alone make it unlikely that the survival and growth of patronage in the Indonesian civil service will be subjected in the medium term to any greater threats than it has been in the past' (Blunt et al., 2012a: 78), suggesting the practical relevance of conceptual critique.

Though we agree with McLeod on the instrumental value of Soeharto's strategy to set the formal salaries of his franchisees low relative to market levels, and [keep] the operating budget for most government entities small relative to their cost' (McLeod, 2008: 222), reversing this to a single factor explanation (and basis for reform) is unwarranted. ${ }^{6}$ As Rosser and Wilson (2012: 268) note, commenting on the health economics and policy literature, 'politics matter much more than these perspectives allow'. As we will show in our analysis of the upeti system as it functions in the irrigation sector, culture, or rather the cultural dimension of politics and economics, also matter much more for both the analysis and practice of institutionalised corruption.

This article highlights the importance of institutions, organisational culture, and social relations, embedded in patronage networks in the overall shaping of corruption rules and practices. In our analysis of institutionalised corruption we make use of Wade's $(1982,1985)$ seminal work on corruption in the irrigation sector in India, which provides a description of the 'systemic' nature of political and administrative corruption with which the Indonesian situation can be usefully

\footnotetext{
${ }^{5}$ This includes the shaping of 'good' policy design and application of 'best practice' as well as an emphasis on the development of legal structures.

${ }^{6}$ The simplification involved shows in the concept of human agency employed - 'government bureaucrats (...), like everyone else, were motivated by self-interest' (McLeod, 2008: 205) Individual self-interest no doubt plays a role in social behaviour, but cannot satisfactorily serve as the single human motivation in explanatory theory.
} 
compared. Wade's work also suggests the importance of the (macro and micro) politics of corruptive practices and their cultural embeddedness.

In terms of policy and practice this leads us to strategies for addressing corruption that incorporates the factors of power [relations] and struggle... which tend to be overlooked by neoinstitutionalist perspectives' (Hadiz, 2004: 697). Anti corruption measures based on 'technocratic rationality' attempting to compensate 'losses' for government officials from not engaging in corrupt practices lack significance, when 'choices' to engage in corrupt practices are defined primarily by institutional protocols and organisational culture, and are thus not entirely based on individuals' economic interest.

Blunt et al. (2012a: 67) emphasise 'factional competition over power and resources' as entry point to combat corruption, highlighting the role of international donors in providing resources for predation and the need to address questions of patronage in development assistance. Their analysis urges international donors to focus their reform efforts on how to build sufficient critical mass to outmuscle the opposition' (Blunt et al., 2012a: 67). For the irrigation sector, this would mean that international donors would have to strategically support segments within the irrigation bureaucracy and the wider society that could act as its allies, rather than imposing the overall idea of reform through standard technical remedies. From our field research in Indonesia, we learn that while such segments might seem non-existent within the formal bureaucratic structure of the irrigation agency, they do exist in the periphery where the boundary between formal and informal (bureaucratic) networks is blurred. In 1998, conditioned by the political climate and the World Bank's support, some mid-career officials from the irrigation agency joined forces with various government ministries, civil society organisations, academics, and political party representatives to push for irrigation reform (Author citation, 2008). We argue that while this movement by itself cannot remove the existing patronage systems, it reflects the very notion of people's power in state governance. ${ }^{7}$ Similarly, the appointment of Indonesia's new

\footnotetext{
${ }^{7}$ See also how new 'breeds' of politicians and political leaders with clean track records are emerging, fifteen years after the fall of the Soeharto's New Order government (Otto and Ismar, 2013).
} 
president: Joko Widodo in October 2014 reveals not only the prevailing people's power in shaping the final outcome of the presidential election, it also sheds light on the people's hope and determination for a better Indonesia. The question remains as how to bundle this power to counteract the dominant interest of 'patronage democracy' (Khan, 2005).

Before we move to our analysis of institutionalised corruption in Indonesia we first describe our research methodology. We then discuss Wade's work, introducing the two main components of our analysis: the system of administrative corruption, that is, the dynamics of corruption within the bureaucratic structure, and the system of political corruption, that is, how corruption practices are embedded in and structure the political system. We describe and analyse in detail the irrigation agency's organisational culture, how this shapes the integrative nature of bureaucratic corruption in the irrigation sector in Indonesia as well as its connection with the wider political system. The three components form a single system, called the upeti system.

\section{Research Methodology}

We use an anthropological approach to corruption ${ }^{8}$ (Harrison, 2006) to understand the insiders' view of rules, mechanisms, and procedures applied in institutionalised corruption. For this we conducted 100 semi-structured interviews with various actors from government ministries, political party representatives, parliament members, academics, and civil society groups as part of the first author's research on irrigation management in Indonesia from September 2003 to February 2005. Apart from secondary literature, project documents and media reports, we refer to these interviews as our main source of data. We conducted 61 semi-structured interviews with officials from the irrigation agency at various administrative levels (national, provincial, district and field level) and 16 interviews with additional sources in other government ministries (i.e. Ministry of Home Affairs, Ministry of Agriculture, National Development Planning Agency). We carried out 23 semi-structured interviews to capture various political party representatives',

\footnotetext{
${ }^{8}$ The approach focuses on the localised meaning of corruption, or how people actually perceive and experience corruption, and thus addresses a central problem of contemporary corruption studies as almost always reflecting the moral opprobrium of outsiders (Sajo, 1998).
} 
parliament members', academics', and civil society groups' perceptions on institutionalised corruption. We start with our first series of interviews at the national level, incorporating officials from the irrigation agencies, other government agencies, as well as other relevant actors operating from the capital Jakarta. The second series of interviews incorporate mainly irrigation agency and other government agency staff at respectively provincial, district, and field level.

From our 100 interview respondents, all acknowledge the existence of the upeti system. Sixtyone interview respondents from the irrigation agency confirm their involvement in the upeti system either as upeti 'distributor' through their role in project management or as direct and/or indirect recipients. Direct recipients are those who receive a certain percentage of project funds, based on their bureaucratic position within the irrigation agency (e.g. high officials, direct supervisors of project heads). Indirect recipients are those who receive financial support related to health, travel, and education expenses from the irrigation agency's 'collective funds', coming from a certain percentage of project funds, and managed directly as the agency's 'social security system'. From our 16 interview respondents from other government ministries and 23 interview respondents from political party representatives, parliament members, academics and civil society groups, all confirm the existence of the upeti system within the irrigation agency. While we rely on information and insights from these 100 interviews as our main source of data, due to widespread commonality in how these respondents view and experience upeti system and practices, we refer only to a number of interview notes in this article.

We use government officials' perceptions, insights and understanding of institutionalised corruption as our starting point for analysis. To distinguish the insiders' view from the outsiders' view, we conducted a series of key informant interviews, where we consult, discuss, and verify our research findings and preliminary analysis with our resource persons at government ministries. To reduce the potential risk of harm to our interview respondents and key informants, we focus our analysis mainly on corruption rules and mechanisms, how they are rooted in the organisational culture of the irrigation agency and its systemic functioning. As most government officials know about this 'general information' identities of our interview respondents remains 
concealed. For the same reason, we do not attempt in this article to use or refer to any specific corruption case within the irrigation agency.

We use the term 'irrigation agency' to refer to the Directorate General of Irrigation (DGI) and the Directorate General of Water Resources and Development (DGWRD), both located under the Ministry of Public Works (MPW). In 1999 the MPW and the DGI were abolished following the anti corruption movement in Abdurrachman Wahid's presidency. In 2003, however, officials from the DGI regained power, initially through the formation of the DGWRD and later through the revival of the MPW (Author citation, 2008). Like the DGI in the past, the DGWRD is in charge for irrigation (water resources) policy formulation and project implementation and equipped with staff from national down to field level.

\section{Corruption as a structural phenomenon in irrigation development}

The most profound analysis of the institutionalisation of corruption in the irrigation sector is Wade's analysis of the system of administrative and political corruption in a South Indian state (Wade, 1982, 1985). ${ }^{9}$ In the 30 years since the publication of these papers, very few additional analyses of similar quality have been produced. ${ }^{10}$ It is only very recently that the analysis of corruption in the water sector has assumed a larger, more systematic scale. The publication of the Global Corruption Report (2008) with a specific chapter on corruption in irrigation systems can

\footnotetext{
${ }^{9}$ For empirical detail, diversity and the complexity of the Indian irrigation corruption system we refer to Wade (1982) and (1984).

${ }^{10}$ Notwithstanding the scarcity of empirical investigations of corruptive practices in the irrigation/water sector, the phenomenon has played an important role in global development discourse, notably the neoliberal 'good governance' perspective. The exemplary paper is Repetto (1986) - a sweeping and seductive analysis, but with very little reference to empirical evidence other than Robert Wade's seminal work on India and evidence on the USA. Corruption, however, is a subject with ample 'tacit knowledge' available. A discussion of the role of corruption in global development discourse is outside the scope of this paper. A study confirming Wade's analysis for a different Indian region and sector is Zwart (1992).
} 
be taken as a marker of this more systematic attention. Yet, the report describes the different forms of corruption practices that take place in irrigation development, referring primarily to the different cycles of irrigation systems development (construction, O\&M, rehabilitation, water distribution), without further analysis of the political structure and organisational foundation underlying this corruption.

In his analysis of 'the market for public office' Wade (1985) shows how within the bureaucracy the transfer from one post to other desirable posts (those with good amenities and big collections), or transfer away from good postings, is governed through market corruption (Scott, 1972). ${ }^{11}$ Government officials have to pay for new postings as part of the formal system of regular transfers, which prescribes transfer within three years. The price for each post reflects the amount expected to be earned from that particular post. These earnings are collected corruption money from primarily construction contracts and to a smaller extent water management. ${ }^{12}$ The market for public office thrives on the uncertainty that is part of the bureaucratic transfer system and its whimsical nature. 'There are no legitimate procedures by which individuals are entitled

${ }^{11}$ Scott (1972) distinguishes two types of corruption: parochial corruption where access to the favors of the power holders was determined by ties of kinship, affection or caste; and market corruption where the same access was granted to those who pay the most regardless of who they are.

${ }^{12}$ In Wade's late 1970s/early 1980s analysis extracting money from the canals, that is requesting bribes from irrigators to secure delivery of scarce canal water, is a significant phenomenon. Intermittent field research of the second author in the same region starting from 1991 suggests that in the course of the past decades the significance of corruption money from water management has declined, and that from physical works thereby relatively increased. One reason for this may be the declining authority and reduced staffing of the Irrigation Department within the large scale irrigation systems (see Mollinga, 2003 for more discussion). This shift in relative importance of sources of corruption money seems not to have affected the institutional structure of corruption as described by Wade. 
to be consulted about their transfers or even to indicate their preferences. No reasons have to be given for a transfer, no appeal procedure is available' (Wade, 1985: 475).

Public choice theory explains the creation of the market for public office by a lack of economic and political competition, and thus the government's dominance to restrict markets through their legislative and regulatory power. ${ }^{13}$ Government domination is apparent in its power to distribute highly lucrative government contracts. Government officials used this dominant position as means to extract rents. With reference to the report of the Santhanam Committee set up in the early 1960s by the Government of India to investigate ways of preventing corruption, Wade points out: 'in all contracts of construction, purchase, sales, and other regular business on behalf of the government, a regular percentage is paid by the parties to the transaction, and this is shared in agreed proportions among the various officials concerned' (Wade, 1985: 480).

A second condition for institutionalised corruption is the bureaucratic career system. Wade identifies the so-called 'closed career system' and the way it shapes government officials' career orientation as a basic premise for the preservation and reproduction of market corruption mechanisms within the government bureaucracy (Wade, 1985). The closed career system has two distinctive features. First, once recruited as part of the bureaucratic personnel, employees mostly will remain in the bureaucracy until their retirement. Second, despite the fact that most officials will remain in the bureaucracy, high-level bureaucratic positions are eligible only to those with certain bureaucratic ranks. Combining these two features, government officials logically focus on the advancement of their bureaucratic career as such to be able to obtain these high level positions. Hence, the market mechanisms described above became the rule for bureaucratic advancement, and thus indirectly force government officials to be corrupt.

${ }^{13}$ See Rose-Ackerman (1999) for elaborate discussion on public choice explanations of corruption. Central in such explanations is Scully's argument on how the size and scope of government intervention positively correlates with corrupt behavior, especially when this intervention acts as the supply of rents (Goel and Nelson, 1998; Scully, 1991). 
The reproduction of the logic of administrative corruption as just described not only depends on factors internal to the bureaucracy: bureaucratic discretion over contracts and the bureaucratic career system. The systemic nature of corruption and its reproduction over time strongly depend on the link with and embeddedness in the political system. That link and embeddedness can be traced by answering two questions: 'who manages the transfer system?' and 'for what is the money collected through administrative corruption used?'

In the Indian irrigation bureaucracy the managers of transfers vary with the position concerned. Lower level officials' transfers are handled by senior bureaucrats, higher level officials transfers are handled by the Minister. At all levels MLAs (Members of the Legislative Assembly, representing geographically defined electoral constituencies) can be, and often are involved. This means that the members of the political arm of the state are the 'top managers' of the transfer system and accumulate considerable amounts of money generated by auctioning transfers. This money is used for financing election campaigns (sometimes including direct financial payments to reproduce followings/buy votes), to reproduce support in between elections, and to satisfy financial demands of higher levels in the political system (like federal state level parties having to contribute to the funding of national campaigns of their party). The logic of maintaining one's position as an MLA, Minister or Chief Minister in the political hierarchy is roughly similar to that of maintaining one's position as an irrigation engineer in the irrigation bureaucracy. Party 'tickets' and cabinet posts cost money, and they require money to be maintained, in relation to competing fellow politicians, and in relation to the 'vote banks'. The political system actively sources money in the bureaucratic system (which is allocated in the political domain in the first place), the crucial lever for which is the control over bureaucratic transfers. ${ }^{14}$ In both domains this logic allows considerable room for personal enrichment.

\footnotetext{
${ }^{14}$ MLAs, Ministers and political parties also share in the benefits of construction contracts. For details see Wade (1982, 1984, 1985).
} 
The Indonesian system of corruption can be analysed using a similar conceptual format of an administrative component (organisational culture that structures bureaucratic rent seeking) that is embedded in the political system and structures corruption within that.

\section{Institutionalised corruption within the Indonesian irrigation agency}

\subsection{Upeti: A modern traditional form}

The Indonesian system of corruption is practiced by strategically blurring 'bribe' with 'token of appreciation'. This mimics a centuries old political system of gift giving: the upeti system (Wertheim, 1970). ${ }^{15}$ Upeti literally means: 'tribute to the king from his followers'. The upeti system was initially applied in the feudal period, where a king's power was measured by the amount of tribute he received from his followers. In return for tribute, the king would protect the local population from outside threats (such as foreign invasion). In modern day Indonesia, the upeti system forms the basis of institutionalised corruption. As stated in Prakoso and Suryati: 'Corruption practices were institutionalised with the establishment of the upeti system' (Prakoso and Suryati, 1986: 27). Government officials focus their career advancement through upeti delivery (in cash and kind) to high ranking officials in return for desirable bureaucratic positions. Established during the New Order government's thirty two years reign upetism continues to be practiced in the post-Soeharto era.

The incorporation of the upeti system into government bureaucratic mechanisms is structurally conditioned by the unification of official and private life within the Indonesian bureaucracy. As stated by Robison: 'The Indonesian bureaucracy is a product of patrimonial bureaucratic authority, in which the demarcation between public and private interest is at best blurred' (Robison, 1978: 24). The upeti system was already applied within the government ministries in

\footnotetext{
${ }^{15}$ See also Yang (1989) on the importance of personal relationship and social exchange in Chinese gift economy of 'guanxi', which highlights the ethics of obligation, reciprocity, mutual aid, and the responsibility of friendship and kinship.
} 
Indonesia prior to the introduction of the so-called project approach ${ }^{16}$ for implementing (donor assisted) development interventions in the late 1960s. However, the project approach has worked as the medium to integrate the existing ('traditional') system into a modern capitalist economy (cf. Riggs (1966) on bureaucratic capitalism), and thus made upetism to continue to flourish.

At a personal level, the application of the upeti system represents government officials' interest in getting private gain (primarily in the form of financial enrichment but not limited to that) from their bureaucratic positions. As a retired official from the irrigation agency stated: 'Nowadays, government agency staff's work orientation is directed primarily by their interest in increasing their personal wealth using their bureaucratic position' (interview with retired official from the irrigation agency, 2003).

Within the Indonesian irrigation agency, institutionalised corruption is practiced as part of project management activities on infrastructure development often funded by international donors. As expressed by official from the Ministry of Agriculture (MoA): "The irrigation agency's technical knowledge and experience enabled them to manipulate the project financial report concerning infrastructure development, in such a way that it is almost impossible for an outsider to discover that the report had been manipulated" (interview with official from MoA, 2003). Furthermore, as stated by an official from the irrigation agency: "The irrigation agency could artificially increase the unit costs for systems construction and rehabilitation without anyone would have ever noticed the flaw in its financial report and actual infrastructure development" (interview with official from the irrigation agency, 2003).

That the practice of upetism continues to be rampant within the irrigation agency in the postSoeharto era is evident from the Public Works minister's speech at the formal inauguration of ministerial high officials, on 6 November 2003. This speech was titled 'No obligation to deliver upeti to high officials'. The minister emphasised the need to eliminate corruption practices rooted

\footnotetext{
${ }^{16}$ Following the adoption of project development approach donor funds are channeled directly to the project management unit. Responsible for the overall management of the unit is a project head.
} 
in the upeti system. In the minister's words: 'I hereby emphasise that the obligation to deliver upeti to high officials should be abolished. Upeti should be forbidden' (speech given by the minister of the Ministry of Public Works under which the irrigation agency is located, as reported in Suara Pembaruan national newspaper, 7 November 2003). While the minister's speech urges the need to abolish the practice of institutionalised corruption within the irrigation agency, it also reveals a set of rules (e.g. informal obligation to deliver upeti to high officials) that resemble the basic norms in institutionalised corruption within the irrigation agency. We argue that it is through the incorporation of these rules and norms into the irrigation agency's organisational culture that corruption becomes institutionalised and forms an integral part of systemic political corruption.

\subsection{The irrigation agency's organisational culture}

Highlighting the importance of cultural dimension in the analysis and practice of institutionalised corruption, we illustrate how the economic logic of institutionalised corruption is embedded in the irrigation agency's organisational culture and structure of social relations (Anand et al., 2005). In particular, we look at how the irrigation agency's organisational values, norms, and behaviour reframe staff's perceptions on corruption as 'desirable' and 'normal' practice ${ }^{17}$ (Anand et al., 2005; Vittel et al., 1993) as revealed in: 1) the establishment of a 'social cocoon' (Ashforth and Anand, 2003); 2) the relationship between project head and his/her bureaucratic supervisor; and 3) the distinction between budgetary and non-budgetary funds.

4.2.1 A social cocoon: The agency's inner circle of power

The practice of upetism within the irrigation agency relies on both the formal system and an informal system of control (Campbell and Goritz, 2014). Senior bureaucrats sustain and reproduce the application of the upeti system through the establishment of irrigation agency staff's inner circles of power or so-called 'social cocoons' (Ashforth and Anand, 2003) at different administrative levels (from national down to sub-district) (see also Eisenstadt and Roniger, 1986; Antlov and Cederoth, 1994 on the history and dynamics of these inner circles of

\footnotetext{
${ }^{17}$ See also Ashforth and Anand (2003) on how organisational culture facilitates the process of 'normalization' in corrupt organisations and shapes staff's behavior.
} 
power). At national level, the inner circle of power comprised of the minister and his/her trusted high officials (both active and retired). At regional level, the inner circle of power consisted of the head of the irrigation agency and his/her close staff at respectively provincial and district levels. Working in concert, this multi level inner circle of power established corruption rules as regard upeti delivery, allocation, and (re)distribution within the irrigation agency. As expressed by mid-career official from the irrigation agency: 'The minister could forbid upeti delivery, but he cannot stop irrigation agency staff to deliver upeti to high officials, even when he wanted to, as long as upeti delivery forms one of the basic requirements for bureaucratic advancement' (interview with mid-career official from the irrigation agency, 2003).

Administratively, this inner circle of power is established in accordance with the defined echelon system. That system categorizes government officials into echelon one (minister and his/her advisory team), echelon two (directors general, directors, inspector general and secretary general), echelon three (head of sections within the directorate), and echelon four (remaining staff). Representing the 'modern bureaucratic state' in Weberian bureaucracy (Weber, 1921), the echelon system features a distribution of authority arranged systematically in accordance with generally applicable rules, and a hierarchy of offices that corresponds with a fixed order of procedural affairs dealt with according to the defined regulations. Within the Indonesian irrigation bureaucracy, however, the system is configured as bureaucratic guideline for institutionalised corruption. Firstly, upeti delivery is channeled from officials from lower echelons to those from higher echelons. Secondly, officials from echelon one and two manage the overall fund allocation originating from the upeti system. Thirdly, while upeti (re) allocation is done with reference to one's position/rank in the echelon system, upeti delivery is distributed equally among officials who hold the same echelon level.

Politically, membership composition of this inner circle of power mirrors the dominant political alliance. During the New Order government the inner circle of power within the irrigation agency was formed following the line of leadership within Golkar as the ruling political party at that time. At the cabinet level, minister positions were held by officials closely linked to Golkar. At the ministerial level, the minister formed his/her inner circle of power through the appointment of party cadres as his/her high officials. At regional level, leadership positions 
within the provincial and district irrigation agency went to officials with connection to Golkar representatives.

In the post-Soeharto era, minister positions continue to be held by officials with close connection with the president and the ruling political party. During Abdurrachman Wahid's presidency, the Ministry of Public Works (MPW) was abolished and replaced by the Ministry of Settlement and Regional Development (Kimbangwil) in 1999. Erna Witoelar, an environmentalist with close connection to Abdurrachman Wahid became the Kimbangwil minister. In 2001 Kimbangwil was replaced with the Ministry of Settlement and Regional Infrastructure (Kimpraswil) following the presidential change from Abdurrachman Wahid to Megawati Soekarnoputri. Soenarno, a senior official at the former MPW and a PDI-P party (the ruling political party at that time) cadre replaced Erna Witoelar and later changed back the name to MPW. At the ministerial level, the irrigation agency's inner circle of power was de-activated with the abolition of the MPW in 1999, but regained its power in 2001 and continues to work in similar way like before.

\subsubsection{The relationship between project head and his/her bureaucratic supervisor}

The practice of upetism within the irrigation agency is centred on the relationship between a project head and his/her bureaucratic supervisors. High officials use their bureaucratic decisionmaking power as a resource to trade bureaucratic positions and ensure upeti delivery from their staff. Data gathered from interviews with various officials from the irrigation agency indicated that officials in the agency would have to deliver money, luxury goods, and additional services to their supervisors to ensure bureaucratic promotion and/or to get a project head position. The latter is considered as one of the best positions in the agency due to the access to project funds that it provides (Author citation, 2008). Similarly, high officials within the agency select their candidate for the project head position primarily based on their interests to use the position as their service point for upeti delivery. Using a similar metaphor as 'service point', a project head is often referred as 'ATM' (automatic teller machine), from which high officials could 'automatically' withdraw their money request (interview with high officials from the MoA and the NDPA). 
Prior to the candidate's appointment as a project head, the future-to-be project head and his/her bureaucratic supervisor agree on their 'informal work relationship', where patronage is rationalized under a notion of 'unstated contract' (Waterbury, 1973). Following their appointments and protected by their bureaucratic supervisors, project heads focus on manipulating the management of project funds in such a way that they can use the funds to deliver an even higher amount of upeti, to ensure their position, if not further bureaucratic promotion.

Contrary to what has been suggested by principal agent theory (Groenendijk, 1997), our analysis shows that institutionalised corruption is driven by shared rather than divergent interests and knowledge between principals and agents. The principal agent model of corruption assumes the reasons for an individual to engage in corruption (say, to pay a bribe) to be located in the tradeoffs between different kinds of costs to effectuate a transaction (such as monitoring costs, bonding costs, and residual loss). In this model there is a difference of interest and knowledge between the principal (the bribe taker) and the agent (the bribe giver). This difference does not exist in the Indonesian case as the (social) relationship between project head and his/her bureaucratic supervisor 'distorts' the very foundation of the assumed trade-offs simply because both the principal and the agent have a shared, common interest in preserving bureaucratic rent seeking practices (Schulte-Nordholt, 1987). As said by a high official from the irrigation agency we interviewed: "The irrigation agency covered all my personal expenses during my holiday tour in Europe together with my wife because my idea to change the dam design has worked very well to reduce the actual cost of dam construction to be significantly lower than the budgeted cost" (interview with a high official from the irrigation agency, 2004). This shared, common interest in preserving bureaucratic rent seeking practices manifested in staff's acceptance of corrupt practices conducted by their peers and bureaucratic supervisors. As stated by an official from the irrigation agency: "When a high official in the irrigation agency invited us to come to his/her luxury house, we gather that s/he could afford such house simply because its total price 
represents only a very small percentage (one percent) of the total budgeted cost for dam construction" (interview with official from the irrigation agency, 2004) ${ }^{18}$.

\subsubsection{Budgetary and non-budgetary funds}

The practice of upetism within the irrigation agency is also supported by an informal system of financial control (Campbell and Goritz, 2014): the so-called 'double book keeping', which refers to the manipulation of project funds through the distinction of project funds into budgetary and non-budgetary funds.

The budgetary fund is an officially registered project fund that is supposed to be used to conduct project activities. The non-budgetary funds are the part of the project fund that is informally used by the irrigation agency to cover its bureaucratic 'expenses', without these expenses being officially registered $^{19}$ (Author citation, 2008). As explained by an official in the Ministry of Agriculture (MoA): 'In general, government ministries in Indonesia have both formal and informal financial systems. The management of this informal financial system varies between ministries, depending on the inter-personal relationship within the particular ministry. Yet, the management of both non-budgetary and budgetary funds is conducted like the two sides of a coin' (interview with an official from the MoA, 2003 and 2004). In addition, a separate book keeping system is maintained next to the formal book keeping. The main difference between the book keeping for budgetary and non-budgetary funds expenditure is that the record of nonbudgetary fund management is never presented to the public. While we never physically saw the books used to record the double book keeping at national level, irrigation agency officials at provincial and district level showed the books to the first author during interviews, confirming not only the standardized corruption rules and mechanisms but also the widespread practice of institutionalised corruption across government administrative levels.

\footnotetext{
${ }^{18}$ This point is also confirmed by other officials from the irrigation agency, MoA, and MoHA we interviewed.

${ }^{19}$ Cf. Lu's (2000) description of the practice of 'small coffers' or secret funds kept by government agencies in the current Chinese system.
} 
The distinction enables the project heads to both register and conceal upeti delivery. Thus, unlike in the principal agent model of corruption, where the principal and the agent have something to hide from each other, in the practice of upetism both the principal and the agent have a shared knowledge on how both fund management systems work and are interconnected, as well as common interest to sustain their functioning.

This 'double book keeping' highlights the role of project financial reports as a mere administrative exercise. Project financial reports do not reflect actual fund management. As stated by mid-career officials from the MoA and the Ministry of Home Affairs (MoHA): 'High officials' role to monitor actual project fund expenditure by the project head became meaningless due to their common interests in manipulating the management of the project fund' (interview with officials from the MoA and the MoHA, 2004). Or as stated in the World Bank report on corruption in Indonesia: 'While there is no shortage of auditing, the audit process is flawed' (World Bank, 2003).

\subsection{Upeti's integrative character and self-generating mechanisms}

The irrigation agency's organisational culture shapes staff's perception of corruption as something 'normal' and 'acceptable'. In line with Hofstede's (1991) four major cultural dimensions: power distance, individualism, masculinity, and uncertainty avoidance, we discuss how institutionalised corruption within the irrigation agency is driven and facilitated by: 1) collective culture within the agency; 2) how less powerful individuals in the agency accept power inequality; 3) value of material success in conjunction with a concern for the weak; and 4) staff's ability to operate in 'uncertain' working environment.

Unlike the neo-institutional economics approach, which assumes that actors act rationally to maximize their self-interest, the upeti system relies on the collective culture within the irrigation agency. This collective culture is most apparent from the project head's role in upeti collection and distribution. As said by a project head we interviewed: "As a project head you have to be able to divide and allocate the funds to reward those that play important roles in securing the funds (e.g. Director General, Secretary General) while at the same time also ensure that funds 
are distributed 'equally' according to one's position in the bureaucratic hierarchy" (interview with official who also hold the position of project head in the irrigation agency, 2004).

Generally, the project head would take ten per cent from the total project fund, while disbursing another twenty per cent to the high officials within the agency (including the secretary general and inspector general in the ministry) regardless of their involvement in project activities. ${ }^{20}$ At provincial level, between ten and fifteen per cent of the remaining funds are directly distributed to the head of the provincial irrigation agency and his close aides. At district level, the project head disburses another ten per cent of the remaining funds among officials in the district irrigation agency (see figure 1$).^{21}$

The project head plays an important role in enlarging the scope and coverage of bureaucratic networks, beyond the formal bureaucratic role and responsibility of government ministries, as well as beyond the distinction between executive and legislative government bodies, and sometimes blurring the distinction between public and private agencies. The project head plays an important role in negotiating with the different parties involved (high officials within the

\footnotetext{
${ }^{20}$ In practice, the percentage received by each actor varies from one project to another, depending on the way the project head negotiates this share with his/her supervisor and the contractors. For example, the contractor would agree to channel twenty per cent of the fund to the high officials if the project head agreed to 'ignore' the marking up in the contractor's proposal. However, the contractor might agree to channel only ten per cent of the fund to the high officials when the negotiation is tiresome, and the project proposal is made strictly, with less possibility for marking up.

${ }^{21}$ As regards order of magnitude of upeti practice across ministries and sectors, the Executive Director (Rizal Ramli) from the Indonesian Economics, Industry and Trade Advisory group estimates that thirty percent of the total amount of foreign loans received by the Indonesian government until 1997 (that is almost US\$ 13 billion) has been lost through corrupt avenues at the national level (Bisnis Indonesia newspaper, 3 September 1998).
} 
irrigation agency, contractors, and the State Audit Agency or BPKP and the Supreme Audit Agency or BPK) on how much they will receive from the mark up of the overall project overhead.

Figure 1: Distribution of project benefits to irrigation agency staff and contractors

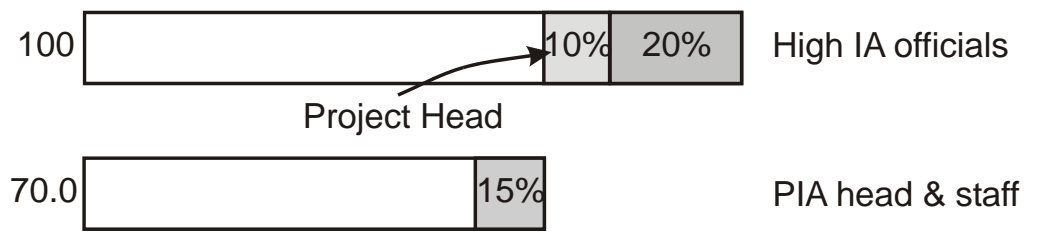

59.5

District IA head \& staff

\subsection{Project Funds}

Contractors

Source: Author citation, $2008^{22}$

By widening his/her corruption network, the project head not only eliminates the risk of participating in corruption activities, s/he also establishes a wide if not all inclusive corruption network, and changes the trend of thinking of the agency staff with regard to corruption. As expressed by a number of the staff in the irrigation agency: 'If one does not participate in corruption practices, one cannot advance one's bureaucratic career within the irrigation agency

\footnotetext{
${ }^{22}$ Data presented in Figure 1 is derived from our interviews with the irrigation agency staff from national down to district level. From our interview respondents across administrative levels (national, provincial, district), we found that the data collected at each level matches with the overall proportion of fund distribution. This shows that actors involved in institutionalised corruption are aware about their share and others'. But most importantly, it confirms the establishment of rules and norms in institutionalised corruption practices as embedded in the irrigation agency's organisational culture.
} 
as one is no longer part of the agency' (interviews with irrigation agency staff, April 2004). Or, as pointed out by Bull and Newell: 'Where systemic corruption develops, then not participating is no longer a sign of honesty, but rather lack of power, weakness or incompetence' (Bull and Newell, 1997: 179).

The upeti system also acts as the irrigation agency's informal ${ }^{23}$ 'social security system'. It regulates the element of personal greed and the importance of interpersonal relationships and to a certain extent concern for the weak through the redistribution of corruption funds to supports the agency's bureaucratic services to its staff. Apart from upeti delivery to each individual official, under instruction of the minister and his/her inner circle of power, the project head would reserve a certain amount from the non-budgetary fund as the agency's financial back-up. Through this reservation, corruption money trickles down to almost all of the irrigation agency's personnel. As said by an official from the irrigation agency: "The irrigation agency covers health, education, and social expenses of its staff (such as when some officials are severely ill, need support to finance their children's higher education, or extra cash to celebrate a wedding ceremony) relying primarily on the reserved funds" (interview with official from the irrigation agency, 2004) ${ }^{24}$. Here, the upeti system functions as a patronage system, where 'the patron [s] look after their followers in a fatherly, moral, and emotional...sense' (Blunt et al., 2012a: 67). Important to note here is the way the agency uses its 'social security' system as a disciplining system, to reward and punish its staff. For instance, the reserved funds can only be used to cover health costs of those officials whose conduct is in line with the irrigation agency's organisational rules (interviews with officials from the irrigation agency, the MoA, MoHA and NDPA, 2003 and 2004).

\footnotetext{
${ }^{23}$ See Robbins (2000) on the role of informal institutions in creating, sustaining and reproducing corruption practices, which contests the current line of thinking that corruption occurs due to the absence of a strong state and a lack of order (Goudie and Stasavage, 1998).

${ }^{24}$ Other officials from the irrigation agency also confirmed this point during our separate interviews.
} 
The way the upeti system functions as a collective tool for funds (if not income) redistribution (Hopkin, 1997) transforms extraordinary stakes of corruption into routine ones, and ensures that corrupted funds are at least or to some extent 'fairly' distributed. Routine stakes are stakes of modest scale, and while often in short supply are at least available on a continuing basis. Extraordinary stakes, on the other hand, are unusually valuable and scarce, such as very large construction contracts (Johnston 1986). Within the upeti system actors do not seek more than what has been allocated to them, as they think that they receive their 'fair' share. This perception of fairness reflects how actors perceive their individual positioning towards the centre of power (Hofstede, 1991) resembled through the irrigation agency's formal hierarchy (referring to the echelon system as well as their connection with the ruling political party). As expressed by midcareer official from the MoA: 'the way the irrigation agency transforms the upeti system as its informal social security system does not only incorporate all staff in institutionalised corruption practices, it also unifies staff's position and view on their 'fair' share of the corrupted fund' (interview with mid-career official from the MoA, 2004). This said, competition between officials does occur from time to time, both in terms of upeti collection and delivery.

Last but not least, the upeti system functions as an informal yet decisive performance evaluation system within the irrigation agency. As one's ability to pull in project funds, negotiate project agreements, and deliver some part of project funds as upeti to his/her bureaucratic supervisor become the main indicators for one's bureaucratic career advancement, officials in the irrigation agency navigate through an 'uncertain' working environment, relying mainly on social relationships with their peers and high officials in the agency.

\section{The upeti system as the foundation of political corruption}

Established during the Soeharto regime, the political relationship between president and his/her ministers continues to be the political foundation of the upeti system in the post Soeharto era. Hadiz (2004: 711) states that this is possible because predatory interests nurtured under the Soeharto regime's formerly vast, centralised system of patronage... have largely survived and 
remain intact'. 25 The ministerial position continues to function as the president's financial resource to sustain and reproduce his/her political power. Here, the minister becomes the president's means to illegally access public money (development funds or foreign loans), which can be channeled to finance the president's political campaigns during the country's national election (Scott, 1969). As a general rule in the post-Soeharto era, a minister's access to sector development funds continues to be the president's crucial weapon to direct the overall outcome of the election, as elections are primarily steered by the practice of both legal and illegal money politics, where a political party can literally buy people's votes relying on their access to government ministerial development funds (Aspinall and Mietzner, 2010).

The president and his/her ministers have a shared interest in sustaining the application of upeti system, in a fashion not dissimilar to the relationship between a project head and his/her supervisors. Government ministers have no reason to fear that the president will report corruption practices within their respective ministry to the parliament or the Supreme Audit Agency, as long as they ensure sufficient amount of upeti delivery to the president. ${ }^{26}$ Similarly, the president has no reason to eliminate rent seeking practices within the government ministries because s/he relies on the upeti delivery from ministers to sustain political power. The current government's promise to eradicate corruption appears little more than empty rhetoric when the president has few incentives to investigate those involved in ransacking the state's public funding (East Asia Forum, 2011). In the eyes of many observers progress with fighting

\footnotetext{
${ }^{25}$ For evidence on the sustenance of these predatory interests see also Sentana and Hariyanto (2013) for the case of institutionalised corruption within the Constitutional Court (one of the highest state's judicial organs). The case focuses on recent allegations made by the Corruption Eradication Commission (KPK) to a top judge for receiving money in relation to his role to monitor vote counts in the political election. ${ }^{26}$ See Nelken and Levi (1996) on how endemic corruption is produced and reproduced through widespread co-optation of almost all sectors within the government, involving not only the executive and parliament members as the main actors in political corruption, but also the judiciary, state audit agency, media and the military.
} 
corruption in Indonesia has been minimal (Blunt et al., 2012a; Hadiz, 2003; Hamilton-Hart, 2001). As said by mid-career official from the irrigation agency: 'To be meaningful, efforts to eliminate rent seeking practices within the irrigation agency should be linked to the wider bureaucratic and political reform' (interview with mid-career official from the irrigation agency, 2004).

Within the context of systemic political corruption, the president gives political allies strategic positions in the cabinet, while replacing those who belong to the political opposition group. In the 1990s, the domination of Soeharto's cronies in government top positions was so obvious that other government officials cynically referred to them as graduates of the 'Cendana University' (World Bank, 2003). Cendana is the street name where Soeharto's family lives. Referring to the street name, Soeharto's family is also referred as the 'Cendana family'. In addition, the president would position his/her most loyal allies in those ministries with huge development budgets, such as the Ministry of Public Works (MPW), under which the irrigation agency operates. In the postSoeharto era, Megawati Soekarnoputri and her ruling political party (PDI-P) applied the same strategy and mechanisms, perhaps with much less systemic outcomes as a result of disintegration of the 'franchise' system (McLeod, 2005). As expressed by an official from the National Development Planning Agency (NDPA): 'During the country's national election, the MPW continued to be one of those ministries informally referred to as the president's 'milk cow', (interview with official from the NDPA, 2003). ${ }^{27}$

At the ministerial level, each minister would appoint his/her staff based also on their political connection with the ruling political party. This nested political connection is important especially if the minister has to cover up financial misconduct in supporting the president's political campaign. In this context, the minister's power is defined by his/her ability to build personal and political alliances within the formal organisational structure of the ministry.

\footnotetext{
${ }^{27}$ The view was supported by officials from the Ministry of Agriculture (MoA) and the Ministry of Home Affairs (MoHA).
} 
In the post-Soeharto era, especially after the direct presidential election in 2004, the upeti system evolved from serving one hegemonic master (Soeharto and his alliance) to multiple masters with various bureaucratic and political background and interests (Khan, 2005). Political relations between the president and his/her ministers evolved from a single party domination (the ruling political party) to multiple parties' political coalition. When Susilo Bambang Yudhoyono became the first Indonesian president directly elected by the people in 2004, his Democratic Party (Partai Demokrat) did not win the election and was not the ruling party. Nevertheless, he preserved the political ties between political party-president-ministers through political coalition with Golkar and other political parties, keeping the political foundation for the upeti system intact, while at the same time also increasing political power of his Democratic Party. This is most apparent from the way he reshuffled his cabinet in 2011 based primarily on 'political transactions' to ensure strategic positioning of his political allies (East Asia Forum, 2011). ${ }^{28}$ While the appointment of Joko Widodo as Indonesia's $7^{\text {th }}$ president in October 2014 may considerably change the political relations between the president and his/her ministers, as evidenced by his close connection with the Corruption Eradication Committee (KPK), strong motivation to strengthen government's ability to deliver better services to the people, and as revealed by strong opposition from the existing political elites (e.g. Red and White Coalition or KMP) to his presidency, this remains to be seen in the coming years of his first term of presidency.

\section{Discussion and conclusions}

In Indonesia institutionalised corruption is produced and reproduced as an integral part of the States' governing structure. Our analysis illustrates how the upeti system survived the political turmoil and regime change in 1998. It highlights the system's ability to adapt to the new bureaucratic and political constellations and reveals the institutional role of corruption as part of the Indonesian government's bureaucratic mechanisms. Our analysis of institutionalised corruption within the irrigation agency provides three main findings.

\footnotetext{
${ }^{28}$ See also Dorling (2011) for evidence that supports the analysis of the sustenance of political partypresident-ministers as the political foundation for the upeti system.
} 
First, it shows that the trade-offs between different kinds of costs to effectuate corruption is determined by the larger institutional set up, beyond one's economic rationale. Our research in Indonesia reveals that rather than thinking in terms of economic gains/losses or driven by rational, self-interested behaviour, quite a number of the irrigation agency staff felt they are 'obliged' to engage in corruption practices simply because they see themselves as part of the larger social cultures and political networks of upetism. As expressed by mid-career official from the irrigation agency: 'One's involvement in corruption practices is linked to one's social relationships and political networks, and less on one's choice and how they perceive corruption practices in the first place' (interview with official from the irrigation agency, 2004). This highlights the importance of social relations and organisational culture embedded in (political) patronage networks in shaping institutionalised corruption, where systemic corruption is shaped through different types of complimentary, intertwining social relationships ranging from bureaucratic patronage (between the project head and his/her supervisor; between high official and his/her staff), business relationships (between the project head and contractor), to political alliances (between president and his/her ministers; the minister and his/her inner circle of power).

Second, our analysis demonstrates how the upeti system prevails over public and legal anti corruption discourses because it is politically grounded and culturally embedded. Unlike the public and legal anti corruption discourses, which are external to the everyday practices of administrative and political corruption, upetism operates within and structures that domain. Putting the notion of gift giving and loyalty to family or clan, rather than the rule of law, central in the practice of institutionalised corruption, the upeti system not only provides psychological atonement for being involved in corruption practices, it also justifies corruption practices as the prevailing social norm. ${ }^{29}$ As said by mid-career official from the irrigation agency: 'Government

\footnotetext{
${ }^{29}$ For an Indian example of the cultural embeddedness of corruption, see Ruud (2002); for its pre-colonial roots in lordship, see Price (1999).
} 
officials involved in corruption practices do not view this involvement as a stigma, but merely as an opportunity to extend their career and income' (interview with official from the NDPA, 2004).

Still related to the second point, our analysis highlights the need for mainstreaming a critical approach to corruption towards the shaping of a more (politically and culturally) grounded anti corruption strategy. Future anti corruption strategy in irrigation sector development cannot be formulated in isolation from the irrigation agency's organisational culture and how this sets the prevailing social norm for institutionalised corruption. While understanding the irrigation agency's organisational culture is crucial to inform the overall shaping of future anti corruption strategy, it is critical for international donors and policy makers to recognize that this organisational culture is also penetrable to internal and external influences. Referring to how some mid-career officials from the irrigation agency initiated policy reform processes in the irrigations sector development through the shaping of strategic alliances involving various government ministries, civil society organizations, academics, and political party representatives, we argue that the formulation of grounded anti corruption strategy should be centered on incorporating needs and aspirations of this pocket of resistance within the irrigation agency. While anti corruption efforts to counter argue and change the prevailing social norm within the irrigation agency can be initiated through external pressures (e.g. donors development agenda, funding conditionality), to be effective, it would need to be internalised into the irrigation agency's organisational culture. As said by mid-career official from the MoA: 'Policy reform cannot rely on external forces alone, but should find its entry point to counter argue the irrigation agency's identity and organizational culture from within' (interview with mid-career official from MoA, 2003). International donors and policy makers could help strengthen the role of this pocket of resistance through their funding conditionality, which required the irrigation agency to work together with accountable agencies and institutions that would act both as partner and third party observer, towards strengthening of the agency's service provision role and its accountability towards farmers. 
This is in line with Blunt et al.'s (2012b) proposition to put the notion of social justice central in anti corruption strategy. The concept of social justice highlights not only the need to allocate 'the greatest benefit to the least advantaged members of society, [but also ensures that] each person [and thus not only those belonging to the government bureaucracy and political system] has equal right to a fully adequate scheme of equal basic rights and liberties' (Rawls, 1985: 227). Giving the notion of social justice central place in the anti corruption agenda could, we suggest, help to reduce the cultural embeddedness of institutionalised corruption by transforming the current dominant perception of corruption from a prevalent social norm to a cultural stigma.

Within the irrigation agency, this 'battle of minds and perceptions' on corruption can be derived from how some mid-career officials in the agency work closely with academics and civil society groups to provide counter arguments on how the irrigation agency continues to focus on infrastructure development as means to mobilise project funds and secure fund sources for institutionalised corruption. As expressed by mid-career official from the irrigation agency: 'A shift from infrastructure-oriented development to field-level interventions to improve service provision towards more equal water delivery could serve as the first building block to contest corruption rules by including farmers into the overall equation' (interview with mid-career official from the irrigation agency, 2004).

This 'battle of minds and perceptions' on corruption would have to be accompanied by appropriate structural change within the existing political system. We propose that anti corruption strategy not only has to represent a combination of top down and bottom up approaches (Pope, 1999), but it also to a certain extent needs to rely on forces and dynamics within the existing political structure, to support and initiate endogenous reform. In this light, Joko Widodo's presidency and his new cabinet (with all its political imperfection) may be an entry point to initiate the envisioned structural change. For example, as the Governor of Jakarta Province (2012-2014), Joko Widodo came up with the idea of e-budgeting as transparent financial mechanism to be applied by government agencies across administrative levels. Later, after winning the presidential election, the new Governor, Basuki Tjahaja Purnama pursued the 
idea further and presented it to the Parliament members, resulting in political struggle that later in the debate unraveled practices of institutionalised corruption in the budget approval system. The new Jakarta Governor's pursuit to apply e-budgeting as a transparent budgeting system for government bureaucracy across administrative levels not only brings to light how the current government attempts to tackle the problem of institutionalised corruption through a more structural approach --by changing the rules of the game- - but also to move beyond the commonly applied approaches to eradicate corruption by legal means (through for instance the current positioning of the Corruption Eradication Committee (KPK)). Understanding and monitoring how this potential game changer materializes in practice is eminent to identify potential pathways and broaden the efforts to fight corruption as part of wider social movement driven in the end by government's and people's aspirations to improve state governance.

Last but not least, the way the upeti system discursively, institutionally and financially integrates administrative and political corruption practices suggests the need for international donors to be more self-consciously politically aware in promoting their development agenda. When corruption practices are facilitated by certain administrative structures, changing (elements of) these structures may reduce corruption. An example would be to create different scenarios in loan repayment (i.e. bilaterally, sectorally, regionally) as part of the overall budget reform (Ma and Ni, 2008; Ngo, 2008) as entry points for anti corruption efforts. Nevertheless, without strong political rooting, there is always a risk that anti corruption measures (no matter how structural they are) would be twisted to serve powerful interests. How to combine people's power and donors' commitment with accountable political leadership) remains the key structural challenge in fighting institutionalised corruption (Gunn, 2014).

\section{References}

Anand, V., Ashforth, B.E., Joshi, M. (2005) 'Business as usual: The acceptance and perpetuation of corruption in organizations', Academy of Management Executive 19 (4): 9-23.

Antlov, H., Cederoth, S. (1994) Leadership on Java: Gentle hints, authoritarian rule. Richmond: Curzon press and Nordic Institute of Asian Studies. 
Ashforth, B.E., Anand, V. (2003) 'The normalization of corruption in organizations', Research in Organizational Behavior 25: 1-52.

Aspinall, E., Mietzner, M. (2010) Problems of democratization in Indonesia: Elections, institutions and society. Singapore: Institute of Southeast Asian Studies.

Aspinall, E., Fealy, G. (2003) Local power and politics in Indonesia: Decentralization and democratization. Singapore: Institute of Southeast Asian Studies.

Bardhan, P. (1997) 'Corruption and development: A review of the issues', Journal of Economic Literature 35 (3): 1320-1346.

Bisnis Indonesia newspaper, Bank dunia dan masyarakat madani siap berantas korupsi, 3 September 1998.

Blunt, P., Turner, M., Lindroth, H. (2012a) 'Patronage's progress in post-Soeharto Indonesia', Public Administration and Development 32: 64-81.

Blunt, P., Turner, M., Lindroth, H. (2012b) 'Patronage, service delivery and social justice in Indonesia', International Journal of Public Administration 35: 214-220.

Bull, M. J., Newell, J. L. (1997) 'New avenues in the study of political corruption', Crime, Law and Social Change 27: 169-183.

Campbell, J.L., Goritz, A.S. (2014) 'Culture corrupts! A qualitative study of organizational culture in corrupt organizations', Journal of Business Ethics 120: 291-311.

Darden, K. (2008) 'The integrity of corrupt states: Graft as an informal state institution', Politics and Society 36 (1): 35-60.

Dorling, P. (2011) Yudhoyono 'abused power'. Sydney Morning Herald, 11 March 2011. http://www.smh.com.au/world/yudhoyono-abused-power-20110311-1bqwj.html.

East Asia Forum. Indonesia's cabinet reshuffle: How low can it go? 1 November 2011.

Eisenstadt, S. N., Roniger, L. (1986) Patrons, clients and friends: Interpersonal relations and the structure of trust in society. Cambridge: Cambridge University Press.

Evers, H. D. (1985) Bureaucratization of Southeast Asia, Working Paper No. 71, Sociology of Development Research Centre, University of Bielefeld.

Ferguson, J. (1997) The anti-politics machine: Development, depoliticisation and bureaucratic power in Lesotho. Minneapolis: University of Minnesota Press.

Global Corruption Report (2008) Berlin: Transparency International. 
Goel, R. K., Nelson, M. A. (1998) 'Corruption and government size: A disaggregated analysis', Public Choice 97: 107-120.

Goudie, A., Stasavage, D. (1998) 'A framework for the analysis of corruption', Crime, Law and Social Change 29: 113-159.

Granovetter, M. (1985) 'Economic action and social structure: The problem of embeddedness', American Journal of Sociology 91 (3): 481-510.

Groenendijk, N. (1997) 'A principal-agent model of corruption', Crime, Law and Social Change 27: 207-229.

Gunn, G.C. (2014) 'Indonesia in 2013: Oligarchs, political tribes, and populists', Asian Survey 54 (1): 47-55.

Hadiz, V.R. (2004) 'Decentralization and democracy in Indonesia: A critique of neoinstitutionalist perspective', Development and Change 35 (4): 697-718.

Hadiz, V.R. (2003) 'Reorganising political power in Indonesia: A reconsideration of so-called 'democratic transitions', The Pacific Review 16 (4): 591-611.

Hamilton-Hart, N. (2001) 'Anti corruption strategies in Indonesia', Bulletin of Indonesian Economic Studies 37 (1): 65-82.

Harrison, E. (2006) 'Unpacking the anti-corruption agenda: Dilemmas for anthropologists', Oxford Development Studies 34 (1): 15-29.

Hellman, J., Kaufmann, D. (2001) 'Confronting the challenge of state capture in transition economies', Finance and Development 38 (3): 1-7.

Hoebink, P. (2007) The Netherlands yearbook on international cooperation. Assen: van Gorcum.

Hofstede, G. (1984) 'The cultural relativity of the quality of life concept', Academy of Management Review 9 (3): 389-398.

Hopkin, J. (1997) 'Political parties, political corruption, and the economic theory of democracy', Crime, Law and Social Change 27: 255-274.

Johnston, M. (1986) 'The political consequences of corruption: A reassessment', Comparative Politics 18 (4): 459-477.

Kaufmann, D., Kraay, A. (2002) Growth without governance. Washington DC: The World Bank. 
Khan, M.H. (2005) 'Markets, states and democracy: Patron-client networks and the case for democracy in developing countries', Democratization 12 (5): 702-724.

Lu, X. (2000) 'Booty socialism, bureau-preneurs, and the state in transition', Comparative Politics April 2000: 273-294.

Ma, J., Ni, X. (2008) 'Toward a clean government in China: Does the budget reform provide a hope?', Crime, Law and Social Change 49: 119-138.

McLeod, R. (2008) 'Inadequate budgets and salaries as instruments for institutionalizing public sector corruption in Indonesia', South East Asia Research 16 (2): 199-223.

McLeod, R. (2005) 'The struggle to regain effective government under democracy in Indonesia', Bulletin of Indonesian Economic Studies 41 (3): 367-386.

McLeod, R. (2000) ‘Government business relations in Soeharto’s Indonesia’, in: P. Drysdale (ed) Reform and recovery in East Asia: The role of the state and economic enterprise, pp. 146-168. London and New York: Routledge.

Moe, T. M. (1989) 'The politics of bureaucratic structure', in: J. E. Chubb and P. E. Peterson (eds.) Can the government govern?, pp. 267-329. Washington DC: The Brooking Institution.

Mollinga, P. P. (2003) On the Waterfront, Water distribution, technology and agrarian change in a South Indian canal irrigation system. Hyderabad: Orient Longman.

Nelken, D., Levi, M. (1996) 'The corruption of politics and the politics of corruption: An overview', Journal of Law and Society 23 (1): 1-17.

Ngo, T. W. (2008) 'Rent-seeking and economic governance in the structural nexus of corruption in China', Crime, Law and Social Change 49: 27-44.

Olken, B.A. (2006) 'Corruption and the costs of redistribution: Micro evidence from Indonesia', Journal of Public Economics 90: 853-870.

Otto, B., Ismar, A. 2013. In Indonesia, a new breed of politicians is on the rise. Wall Street Journal, 9 October 2013.

Pope, J. (1999) 'Elements of a successful anticorruption strategy', in: R. Stapenhurst and S. Kpundeh (eds.) Curbing corruption: Toward a model for building national integrity, pp. 97-104. Washington DC: The World Bank.

Prakoso, D., Suryati, A. (1986) Upetisme: Ditinjau dari Undang-Undang pemberantasan tindak pidana korupsi tahun 1971. Jakarta: Bina Aksara. 
Price, P. (1999) 'Cosmologis and corruption in (South) India: Thinking aloud', Forum for Development Studies 26 (2): 315-327.

Rawls, J. (1985) 'Justice as fairness: Political not metaphysical', Philosophy and Public Affairs 14 (3): 223-251.

Report of the Committee on the prevention of corruption (Santhanam Report) (1964) New Delhi, Ministry of Home Affairs, Government of India.

Reppeto, R. (1986) Skimming the water: Rent-seeking and the performance of public irrigation systems, Research report No. 4. World Resources Institute: Washington DC.

Riggs, F. W. (1966) Thailand: The modernization of a bureaucratic polity. Honolulu: East-West Center Press.

Ringskog, K. (2001) Opportunity in crisis, Opening speech for the International Seminar on Water Supply and Sanitation Sector Reform in the Context of Regional Autonomy, Jakarta, 21 23 May 2001.

Robbins, P. (2000) 'The rotten institution: Corruption in natural resource management', Political Geography 19: 423-443.

Robison, R. (1978) 'Toward a class analysis of the Indonesian military bureaucratic state', Indonesia 25: 17-39.

Rose-Ackerman, S. (1999) Corruption and government: Causes, consequences and reform. New York: Cambridge University Press.

Rosser, A., Wilson, I. (2012) 'Democratic decentralization and pro-poor policy reform in Indonesia: The politics of health insurance for the poor in Jembrana and Tabanan', Asian Journal of Social Science 40 (5-6): 608-634.

Ruud, A.E. (2000) 'Corruption as everyday practice: The public-private divide in local Indian society', Forum for Development Studies 2 (2000): 271-294.

Sajo, A. (1998) 'Corruption, clientelism and the future of the constitutional state in Eastern Europe', East Europe Constitutional Review 7: 37-46.

Schulte-Nordholt, H. G. C. (2003) 'Renegotiating boundaries: Access, agency and identity in post-Suharto Indonesia', Bijdragen tot de Taal-Land-en-Volkenkunde 159 (4): 550-589.

Schulte-Nordholt, N. G. (1987) 'State-citizen relations in Suharto's Indonesia: Kawula gusti', CASP 16, Erasmus University, Rotterdam. 
Scott, J. C. (1972) Comparative political corruption. Prentice-Hall: Englewood Cliffs.

Scott, J. C. (1969) 'Corruption, machine politics, and political change', The American Political Science Review 63(4): 1142-1158.

Scully, G. W. (1991) 'Rent seeking in US government budgets 1900-1988', Public Choice 70: 99-106.

Sentana, I. M., Hariyanto, J. (2013) Indonesia holds a top judge. Wall Street Journal, 3 October 2013.

Smith, J., Obidzinski, K., Subarudi, Suramenggala, I. (2003) 'Illegal logging, collusive corruption and fragmented governments in Kalimantan, Indonesia', International Forestry Review 5 (3): 293-302.

Suara Pembaruan newspaper, No obligation to deliver upeti to high officials, 7 November 2003.

The Jakarta Post, Corruption ingrained in procurement processes, Jakarta 2 May 2009.

Treisman, D. (2007) 'What have we learned about the causes of corruption from ten years of cross national empirical research?', Annual Review of Political Science 10: 211-244.

Vitell, S.J., Nwachukwu, S.L., Barnes, J.H. (1993) 'The effects of culture on ethical decision making: An application of Hofstede's typology', Journal of Business Ethics 12: 753-760.

Wade, R. (1985) 'The market for public office: Why the Indian State is not better at development', World Development 13 (4): 467-497.

Wade, R. (1984) 'Irrigation reform in the conditions of populist anarchy: An Indian case', Journal of Development Economics 14: 285-303.

Wade, R. (1982) 'The system of administrative and political corruption: Canal irrigation in South India', Journal of Development Studies 18 (3): 287-328.

Waterbury, J. (1973) 'Endemic and planned corruption in a monarchical regime', World Politics 25 (4): 533-555.

Weber, M. (1968) Max Weber on law in economy and society. New York: Simon and Schuster. Wertheim, W.F. (1970) 'Sociological aspects of corruption in Southeast Asia', in: A. J. Heidenheimer (ed.) Political corruption: Readings in comparative analysis. pp. 195-211. New Jersey: New Brunswick. 
Accepted Version downloaded from SOAS Research Online: http://eprints.soas.ac.uk/22541/

World Bank, (2003) Combating corruption in Indonesia: Enhancing accountability for development, Washington D.C., East Asia Poverty Reduction and Management Unit, The World Bank.

Yang, M. (1989) 'The gift economy and state power in China', Comparative Studies in Society and History 31 (1): 25-54.

Zwart, F. de. (1992) 'Mobiele bureaucratie. Manipulaties met overplaatsingen van ambtenaren in India', $\mathrm{PhD}$ dissertation, University of Amsterdam, Amsterdam. 